\title{
The Law Analyze and Background of the Development of the Albanian and Kosovo Economy
}

\author{
1Msc Ledja Kingji \\ 2PhD.c Xhenet Syka \\ 3Prof Dr Alba Dumi \\ 1,2 Law Faculty, University of Vlore, Albania \\ 3Management Department" Economy Faculty University of Vlore, Albania; Email: alba.besi12@gmail.com
}

Doi:10.5901/ajis.2016.v5n2p95

\begin{abstract}
The purpose of this paper is the identification of the relationship between exchange rate and inflation directly and indirectly having their factors in the stability and development of the economy. Identification of variables that determine the behavior of the exchange rate in Albania, as in periods longer-term and short-term analysis of the causes that lead to us to avoidance of the balance of the exchange rate and the consequences arising from such deviation. The findings and analysis, conclusions and recommendations which will be part of important scientific studies in this paper that will serve to assist in the preservation of natural resources in our countries. Another purpose is the direct impact analysis that has the exchange rate of macro economic factors such as economic growth, inflation and employment levels.
\end{abstract}

Keywords: Inflation models, exchange rate, empirical studies, National instruments.

\section{Introduction}

For too long numerous researchers have attempted to find a link between the movement of the exchange rate and inflation in the country. Initially there were models that assumed a unitary link between the exchange rate and inflation, based on the theory of law in the price. Later from numerous studies were models of purchasing power parity, where this model was used to fully identify the movement of the exchange rate in extensive. Testet empirical did not supported this assumption and consequently it is supposed that this movement of the exchange rate is not fully reflected in price levels. Already there are many models / theories that explain why such disregard is incomplete.

\subsection{The aim of this study, data analyze}

The aim of this study is to provide empirical evidence on the extent of the contempt of the exchange rate with the rate of inflation in Albania. The study of this connection is motivated by the impact that has the exchange rate in an economy as small and open economy is Albanian. Given the importance of the exchange rate on the main elements of the economy, the Central Bank has not ignored the developments in the exchange rate in Lek, although the conditions were of floating exchange rates. (Ruli G, 2007)

These developments are closely monitored by the Central Bank and in certain moments it has intervened through monetary policy to avoid fluctuations regarded the distorting. This is done because the exchange rate is one of the main variables involved in the process of forecasting inflation. (Guxholli Z, 2009)

Always the question arises: Should the Central Bank pay importance to exchange rate movement and to what extent? Should this attention be too large enough to include the exchange rate of the Taylor Rule?

So should CB respond to exchange rate changes and further to whose nominal exchange or a real one? These questions are complicated even more in the moment when interventions on the exchange rate is defined as a tool of monetary policy to achieve the objectives of the other secondary as: increasing international reserves,facilitating in shortterm fluctuations arising due to the characteristics of an economy small, open and regulate the exchange rate when it leaves the basic rules.

H1: But how these policies can be used with inflation targeting? 


\section{The Purpose of the Study}

In 1999 Balli took into account these problems and included the exchange rate as an explanatory variable in the equation of the aggregate supply and demand, where the exchange rate is expressed as a function of the interest rate and as probable casual error. An inclusion in these two equations is done because the Taylor rule for defining an optimal policy should be modified, taking into account the most direct way in determining exchange rates of monetary policy instruments. (Dumi A, Leadership, 2016)

And therefore the new rule is not opposed targeting inflation, but simply makes the determination that accounts for monetary policy and exchange the real rate volatility, as well as the impact of exchange rate interventions on interest rate.

H2: In 2000 the Svenssin argue that the inclusion of the exchange rate in the Taylor rule being most likely to provide macroeconomic accurate and stable results.

Both these authors propose optimal values for coefficients of exchange rates, which may change, however, due to the specific characteristics in the model and changes in parameters, therefore, such rules are not very sustainable practicable. Other authors like Mishkin and Savastano 2001 and Schimit-Hebbel argued that in a properly defined model, the facts included indirect exchange rate policy in the rules, including the function of losses through its effects on the output gap and inflation. In general, the issue remains unresolved, because the issue in connection with the exchange rate is not treated in full in the targeting literature and inflation. (Dumi A, Mjss 2012).

This literature is concentrated in the monetary model of closed economy and does not become a better comparative analysis of the facts of welfare or macroeconomic development, when the exchange rate is included in the rules of monetary policy.

\section{Literature Review And Hypotheses}

To give an answer as best as possible to this issue will be based the empirical research, due to the different specific factors in economy of the country. In 2005 Mohanty and Klau have made a research in 13 different countries which have an economy in transition and in developing, this is for the hypothesis that the exchange rate belongs to monetary reaction function.

The result of this study shows that different coefficients of the exchange rate are significant in 11 countries out of 13 , indicating that $\mathrm{BQ}$ of these countries are taking into considerations the drafting exchange rate and implementation of monetary policy. But, which is the user of publications monetary policies concerning the development of the exchange rate in our country?

To give an answer to this question based on the Taylor rule in an open economy. In our country the exchange rate has an impact on decisions to CB for monetary policy and to calculate the reaction function of the policy interest rate in an open economy and many authors are based on the rules of Taylor, which includes the effects of exchange rate movements in relation to inflation and the output gap.

The central change in the use of nominal exchange effects in place of the real one, and the argument that the policies developed by $\mathrm{CB}$ of Albania aims to mitigate the various speculative attacks and sudden fluctuations in the nominal exchange currency exchange.

Exchange rate considered as a significant honor channels of transmission mechanism of monetary policy in Eastern Europe, while the issue of contempt of exchange rate on prices is less explored. This study contributes to the enrichment of the literature of the countries on the role of the exchange rate in price formation.

During the transition period Albania moved from a closed economy and regulated in an open market economy. This move was accompanied with great shock and destruction of macroeconomic balances.

The Opening of the economy itself is an important factor for the restructuring of the economy and to increase its efficiency. Two of the main indicators of the transition of the Albanian economy are the exchange rate and the index of the prices of goods of the consumer.

At the beginning of the liberalization of the economy the exchange rate and consumer prices were one of the first indicators that began to change rapidly.

On the one hand, this change shows adaptation of the free market philosophy. On the other hand, these indicators began to be used as criteria of speed and the changing character of the general conditions of the economy.

From the standpoint of economic theory between these two indicators there is a connection and a dependence because:

The first, a good part of the Albanian consumer goods are coming from imports and as consequence the highest 
foreign currencies will be,the highest the consumer prices will bw in the internal markets. Secondly, the exchange rate would rise as a result of liberalization of the economy, by adapting mechanism of demand and supply. By rising the domestic demand customers, it has increased not only the price but also has increased the demand for Valut and is therefore increasing its price. Albania has an agreement with all countries that are part of the EU and this has affected all elements of the economy. The first step of the transition process in 1991 was the liberalization of prices and foreign trade.

In order to achieve macroeconomic stability in an environment where inflation was higher that it came as a result of price liberalization, monetary policy set as its main objective of price stability which meant the central bank independence. To achieve this objective the Central Bank was focused to control the money supply. At the beginning in Albania is used exchange administrative parts and under this regime the country could not follow independent monetary policy and as consequence $\mathrm{CB}$ need to intervene in the foreign exchange market every time the rate of exchange was different from the official rate using the official reserve transactions. After the transition in Albania began to be used with the flexible exchange rate which depended mainly on the macroeconomic situation in the beginning of the transition process. (Calvo, G.A. 1999)

\section{Research Goal}

In the case of Albania maintaining macroeconomic interior balancing in terms of liberalization of the economy constitutes a major challenge for our economy has a huge deficit of current account and a high trade deficit. It is very important to preserve macroeconomic stability, which means achieving a balance in terms of the full employment, stabilizing prices and the unemployment rate From numerous studies that have been made and have also been raised a number of questions such as:

1- Economic transition has been completed in Albania and what are the achievements, failures and challenges in the future of this transition?

2- Albania's economy needs for a restructuring and what standpoint will have the macroeconomic stability, budgetary control and the most important to get control over public debt?

3- Which will be priorities in the economic development of Albania and how these priorities will be based on the use of internal resources and how coherent it will be the newest development of global development.

4- Is ready the economy of Albania to pass over a developed economy, exporting, competing and integrated into regional and continental range?

5- What reforms will be taken to expand economic freedom and to enhance the role of business for local and foreign investments in the economy of our country?

6- What role will play the economic diplomacy, and who will be the new perspective of the international cooperation with suitable financial institutions.

According to assessments made by the IMF, Albania's economy is characterized by a positive growth development in recent years, this thing is shown by the pace of sustainable economic growth, promote continual improvement of economic stability and the gradual approximation of the structure of the economy with them of developed economies. (Calvo, G.A. 1999)

Developments in the foreign exchange market have followed the progress of the international market, without compromising the macro-economic balance in the country.

The topic is organized into three main chapters. In the first chapter is provided an overview of economic development and the aspirations of our country to become part of the European Union. (Bahmani Oskooee, M., Tanku A., 2006)

In the second chapter is given an abbreviated description of theories on exchange rate and the impact that has it in the evaluation of local currency, inflation and the performance of the main factors that determine the exchange rate and inflation. In the third chapter will be an empirical and econometric analysis of the relationship between exchange rates and inflation, and also analysis of probabilistic methods used in Albania for measuring inflation. To make the econometric analysis of time series are obtained with the monthly data for the period 1994-2011 in Albania, and to describe the dynamics of the exchange rate and inflation is used ANOVA methods.

\section{Sample and Data Collections}

The last part contains the main conclusions drawn from the analysis of the connection that the exchange rate to inflation. Verification of hypotheses and questions that are raised for inflation connection with other elements of macro economic. 


\subsection{Albanian economic development}

The development of Albania's economy has gone through this major periods.

a- 1991-in this period the country's economy was dominated by a decrease in real GDP social and economic disruption. In this period, we have a higher inflation rate during this period. We have a decrease by two thirds of the level of income and inflation compared with 1989. (Calvo, G.A. 1999)

b- 1993-96 -during this period, we have a recovery GDP grew by $10 \%$ and therefore lower inflation and trade deficit and fiscal improved significantly. This was achieved as a result of monetary and fiscal policy which makes the landing pressure on prices.

c- During 1996 have a fluctuation in the growth. This came as a result of errors in economic stabilization policies. Revenue collection fell and consequently the fiscal deficit began to grow.

To with stand competition, technology development or the need for the addition of new services, it is necessary to supply the company with new human resources staff. Technology, products and types of services are some of the features that make the difference of companies in the market.

However, these will not have any value if the employee does not meet the required qualities. The lack of clear plans for staff training (or funds) staff faced different difficulties during labor processes, in managing people or dealing with market competition. (Bahmani Oskooee, M., Tanku A., 2006)

So, it set up a special department that deals with labor force or human capital differently, called the human resources department. Department of Human Resources in Western countries and especially in the US (where there was born) has moved forward by aiming to become the first country where business leaders will go for advice. (Figure 1)

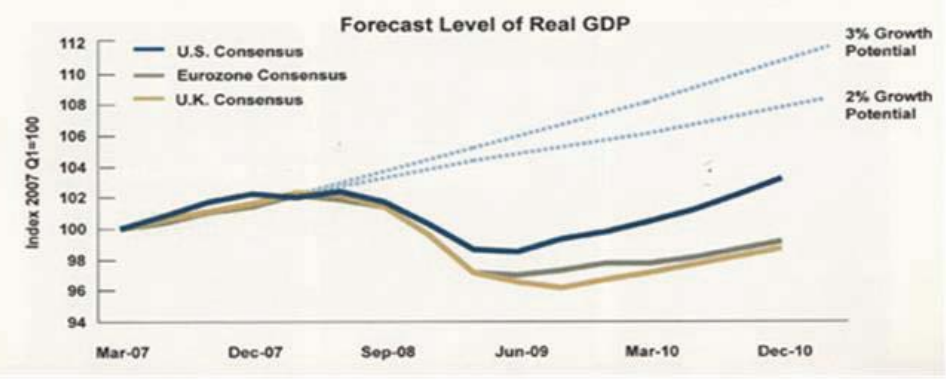

Figure 1. GDP level Burimi: Financial planning (2007-2010)

As we see from the graph the US has a potential growth of $3 \%$, while the eurozone and the UK increased by $2 \%$, of course, affect other factors but mainly influenced specialization and qualification of human resources.

What is the real profit that take businesses from investing in training employees? Saying otherwise, when and how much business will benefit economically from these trainings?

Establishment of a system of HR data and advances in technology has produced software and other technology that can analyze information provided help many business HR and uncover the connection between labor productivity and talent management. (Calvo, G.A. 1999)

Many leaders of companies obliged by the consolidation of work HR have already taken the first steps towards measurement and reporting of the cost and performance of HR. Being aware and accepting that special practices related to human resources of various companies vary (change) by the dynamics of the various companies, lack of talent, growth rates, business culture, etc, all these lead to answer that organizations and businesses that earn more by investing in HR will have a better economic performance.

\subsection{The empirical analysis of the expected rate of inflation.}

To evaluate and control the empirical features of inflation and expectations with respect to fluctuations of the rate it is very important to ensure public information and this information back in time series which will help in its determining. Often this process is difficult because the errors in the process of aggregation and generation of data are large. 


\section{Human Resources in the Face of Crisis}

In the US, the effects of the crisis which is being felt around the world have been registered about 2.2 million job closed. So close the factories of raw materials has led to loss of jobs for 1200 employees of the company "Marks \& Spencer". Nissan Company records $\$ 2.9$ billion loss for the first time in 9 years and 20,000 workers unemployed. (Paukert, 2009)

Dealing with the crisis means the tendency toward stagnation or orientation towards security forces and the survival of the human resources in the workplace, in order to have economic recovery. (Calvo, G.A. 1999)

Employees led by job insecurity, or in cases when they realize that the company is investing in the development of their capacities, often tend to look for other employment alternatives. Due to the different economic phenomenal that brings the economic crisis (inflation, rising prices) employees are more sensitive to the level of their salary and wage increases tend to seek or ask for a job that are paid more. (Dumi A, Leadership 2016)

We havePeeters study in 2005. He focused more on the perception thatsaving exchange channel is the main channel of transmission of monetary policy in Albania. Completion of this study was that the importance of this channel has declined as a result of using the credit channel and the wage channel where these have become an essential element over the years.

\section{Conclusions}

The exchange rate is very important for countries in development also for developed countries too. In the longer term the exchange rate is affected by product of economy sectors between Albania and other countries, remittances and openings and trade agreements. In the short term the exchange rate is influenced by debt service and government spending. Through econometric analysis have been achieved the following conclusions:

1- External influences, resulting in stabilization of the exchange rate played an important role in maintaining a low inflation rate in most of the time.

2- Monetary policies have increased resulting in more stability and predictability in relation to changes in the money supply and in price levels. The introduction of direct instruments of monetary Policy has had a direct impact on improving the economy.

3- Monetary policies aimed at maintaining a low inflation also has a negative side because the movement towards an inflation target regime can contain short-term risks.

4- Between the consumer price index and the exchange rate, there is a strong positive correlation which is statistically significant. Comparing the periods before and after 1997 there are many important structural changes which have had a greater impact on the domestic economy.

5- Changes in the consumer price index was preceded changes in exchange rates. This thing is shown by equation (4) where for each Lek of exchange rate there is an average increasing of $0.942 \%$ of the consumer price index.

\section{References}

Hollar, (2003), "Causes and Consequences of Real Exchange Rate Appreciation".

Raporti vjetor i Tregtisë së Jashtme, 2006.

Raporti vjetor i Bankës së Shqiperisë, 2005, 2006.

Buletini Ekonomik i Bankës së Shqipërisë, mars 2007,vëllimi 10.

Ball, Laurence (1999), "Policy Rules for Open Economies, "in Monetary Policy Rules edition by John B. Talor, University of Chicago Press, 1999, pp 127-44.

Bahmani Oskooee, M., Tanku A., 2006, "Black Market Exchange Rate, Currency Substitution and Demand for Money in LDCs." Economic Systems, 2006, Vol. 30. pp.249-263

Calvo, G.A. 1999, "Fixed versus Flexible Exchange Rates: Preliminaries of a Turn-of-Millennium Rematch." University of Maryland .Calvo,

G.A., and C. Reinhart, 2002, "Fear of Floating."Quarterly Journal of Economics, Vol 11 7, No.2.

Campa, J.M. and L.S. Goldberg, 2002, "Exchange Rate Pass-through Import Prices: A Macro or a Micro Phenomenon?" NBE R Working Paper 934, Cambridge, Mass. 
